ks. Marek Jagodziński

Katolicki Uniwersytet Lubelski Jana Pawła II

DOI: 10.15290/std.2017.03.04

\title{
„ZWYCZAJNE” DZIAEANIE BOGA W SAKRAMENTACH W KONTEKŚCIE KONTROWERSYJNYCH KONCEPCJI TEOLOGICZNO-PASTORALNYCH
}

\section{"ORDINARY" ACTION OF GOD IN THE SACRAMENTS IN THE CONTEXT OF THE CONTROVERSIAL THEOLOGICAL-PASTORAL CONCEPTS}

God acts "ordinary" through the sacraments of the Church and saves us from sin, however always remains open for us a question about the way of salvation. In the space of theological researches and their pastoral applications, however, controversial concepts have emerged, raising a number of questions and doubts that demand a critical assessment. These include concepts of "generational sin", "intergenerational forgiveness" and "wicket's confession". Theological reflection and the involvement of the pastors of the Church in Poland brought with them concrete results in the form of competent theological opinions and disciplinary regulations, and this whole process has become an opportunity to deepen the awareness of God's action in the sacraments of baptism and penance, as well as the theological-pastoral challenge.

Key words: sin, sacrament of baptism, sacrament of penance, forgiveness of sins, salvation, "generational sin", " intergenerational forgiveness ", "wicket's confession". 
Między łaską i nadprzyrodzonością a naturą, naturalnością, nadnaturalnością i nadzwyczajnością jest miejsce dla życia człowieka poszukującego Zbawienia. Dla chrześcijanina nie ulega żadnej wątpliwości, że zbawić nas może tylko Jezus Chrystus. Nieustannie towarzyszy nam jednak pytanie, w jaki sposób nas zbawia? Niepojęte działanie Boga staje się dzięki zaangażowanemu w nie Kościołowi w pewien sposób „zwyczajne”. Do tej „zwyczajności” zalicza się także moc i działanie sakramentów. Katechizm Kościoła Katolickiego stwierdza:

Sakramenty [...] udzielają łaski, którą oznaczają ${ }^{1}$ Są one skuteczne, ponieważ działa w nich sam Chrystus: to On chrzci, to On działa w sakramentach, aby udzielać łaski, jaką oznacza sakrament. Ojciec zawsze wysłuchuje modlitwy Kościoła swego Syna, który to Kościół w epiklezie każdego sakramentu wyraża swoją wiarę w moc Ducha Świętego. Jak ogień przemienia w siebie wszystko, czego dotknie, tak Duch Święty przekształca w życie Boże to, co jest poddane Jego mocy. Taki jest sens stwierdzenia Kościoła, że sakramenty działają ex opere operato (dosłownie: „przez sam fakt spełnienia czynności”), czyli mocą zbawczego dzieła Chrystusa, dokonanego raz na zawsze. [...] gdy sakrament jest celebrowany zgodnie z intencją Kościoła, moc Chrystusa i Jego Ducha działa w nim i przez niego, niezależnie od osobistej świętości szafarza (nr 1127n).

Bernard Sesboüé podkreśla, iż byłoby nie do pomyślenia, żeby w teologii ograniczać się tylko do ponownego odczytywania tradycji, gdyż

ludzki dyskurs z pewnością nigdy nie zdoła ogarnąć bogactwa misterium, którego nie sposób zawrzeć w słowach. [...] Dlatego wyrażanie naszej wiary w Zbawienie przyniesione przez Jezusa Chrystusa, jedynego Pośrednika, wymaga nieustannego ponawiania wysiłku - po to, byśmy starali się udzielać odpowiedzi na pytania naszej

$1 \quad$ „Każdy sakrament jest widzialnym znakiem niewidzialnej łaski. Każdy sakrament jest widzialnością niewidzialnego wydarzenia, które go radykalnie przerasta. Sprawdza się to w najwyższym stopniu w liturgii eucharystycznej, gdzie to, co widzialne i oznaczające (zgromadzenie, słowo, modlitwa eucharystyczna, łamanie chlebai komunia), jest niewspółmierne wobec tego, co niewidzialne i oznaczane (sakramentalna pamiątka ofiary Jezusa i - na ostatnim miejscu - konstytuowanie ludu Bożego jako ciała Chrystusa). Również Kościól, jako wielki sakrament Zbawienia w sprecyzowanym wyżej znaczeniu, odsyła do rzeczywistości, która nieskończenie go przerasta. Sakramenty bowiem «pokrywają się [...] z ową tajemniczą rzeczywistością, w której ten sam Bóg, który wkroczył w historię ludzi, przychodzi do nich pod zasłoną i w przejrzystości znaków, aby poświadczyć swoją obecność oraz żyć razem z nimi i w nich jako ich sprzymierzeniec». Zasłona i zarazem przejrzystość - oto właściwość sakramentu. Zasłona zawsze gęsta dla rzeczywistości, przejrzystość cienka i krucha - one zachowują jego charakter znaku i ocalają więź sprawczości. Bowiem «sakramentalny znak wyraża jednocześnie dystans i rzeczywistą więź między widzialnym wyrazem a niewidzialną rzeczywistością, na którą mamy nadzieję»" (B. Sesboüé, Jezus Chrystus jedyny Pośrednik. Rzecz o odkupieniu i zbawieniu, t. II: Opowiadania o zbawieniu. Propozycja soteriologii narratywnej, tł. A. Kuryś, Poznań 2016, s. 386). 
kultury i naszych czasów, w miarę możliwości wykorzystując w badaniach nad Pismem Świętym i Tradycją wszelkie nowe odkrycie i metody, jakimi dysponujemy².

W tej przestrzeni poszukiwań teologicznych i ich aplikacji duszpasterskich pojawiają się jednak od czasu do czasu koncepcje, które są kontrowersyjne, budzą szereg znaków zapytania i wątpliwości oraz - nie negując dobrych zamiarów ich zwolenników - domagają się krytycznej oceny, a czasami także ich odrzucenia ${ }^{3}$. Do nich należą koncepcje „grzechu pokoleniowego”, „przebaczenia międzypokoleniowego” i „spowiedzi furtkowej”.

Por. ibidem, s. 9n. Dokument Papieskiej Komisji Biblijnej Interpretacja Pisma Świętego w Kościele (1993) w rozdziale o interpretacji Biblii w życiu Kościoła mówi także o konieczności jej aktualizacji: „Aktualizacja powinna mieć ciągle na uwadze relacje, jakie istnieją w samej Biblii po chrześcijańsku pojmowanej, pomiędzy Nowym a Starym Testamentem, a zwłaszcza to, że Nowy Testament jest nie tylko dopełnieniem, ale i swoistym «przekroczeniem» Starego Testamentu. Aktualizacja dokonuje się przy pełnym poszanowaniu tak rozumianej dynamiki. Aktualizacja urzeczywistnia się dzięki dynamicznej żywotności Tradycji całej wspólnoty wiary. Wspólnota owa znajduje się bardzo wyraźnie na linii przedłużenia tych wspólnot, w łonie których rodziły się i były przekazywane treści żywej Tradycji. W procesie aktualizacji Tradycja spełnia podwójną rolę: $z$ jednej strony stanowi osłonę przed błędnymi interpretacjami Pisma Świętego, z drugiej strony zaś zapewnia siłom pierwotnego dynamizmu ich dalszy przekaz. Aktualizacja nie oznacza więc manipulowania tekstami. Nie chodzi o to, żeby w związku z tekstami biblijnymi ogłaszać jakieś nowe opinie albo prezentować nieznane dotąd ideologie; chodzi o rzetelne poszukiwanie światła, jakie te teksty mogą rzucać także na nasze czasy" (Interpretacja Pisma Świętego w Kościele. Przemówienie Ojca Świętego Jana Pawła II oraz Dokument Papieskiej Komisji Biblijnej, tł. K. Romaniuk, Poznań 1994, s. 99). Dokument ten wspomina także o psychologicznym i psychoanalitycznym podejściu do Biblii, pomagającym w jej zrozumieniu, ale dialog interdyscyplinarny powinien mieć charakter krytyczny, „powinien też respektować granice każdej z tych dyscyplin" (ibidem, s. 51).

3 „Nie ujmując niczego szlachetnej intencji pomagania ludziom cierpiącym, dla teologa istotny będzie zawsze w tej kwestii kontekst biblijny, odpowiednia hermeneutyka przywoływanych tekstów biblijnych, tradycja teologiczna Kościoła i pojawiające się problemy dogmatyczne” (M. Jagodziński, Czy istnieje kwestia „przebaczenia międzypokoleniowego”?, „Roczniki Teologiczne”, t. LXIII, z. 2 (2016), s. 156). Ciekawa jest wypowiedź teologa prawosławnego: „człowiek to istota meandryczna. [...] element duchowy i fizyczny przenikają się wzajemnie, tworząc bardzo bogatą kompilację duchowo-fizyczną. Strona psychologiczna nie może istnieć w pojęciu chrześcijańskim bez strony teologicznej, antropologicznej, dlatego też zawsze powinny być tutaj brane pod uwagę dwa elementy: psychologia i dogmatyka chrześcijańska. Dogmatyka w tym związku pełni rolę «stróża», który kontroluje poczynania psychologii, nauki bardzo obszernej, zwłaszcza wtedy, gdy argumentacja psychologiczna opiera się na rozumowaniu dedukcyjnym. Dogmatyka w tym układzie kładzie fundament, na którym pozwala budować psychologii. To, co wykracza poza ten fundament, jest niwelowane. W ten sposób psychologia może pracować w ramach chrześcijańskiej ortodoksji. Jest to bardzo ważne, szczególnie w przypadku sakramentu spowiedzi, w którym przenikają się kwestie psychologiczne i dogmatyczne" (P. Fiedoruk, Bosko-ludzka relacja w sakramencie spowiedzi, [w:] Pokuta w życiu chrześcijańskim, M. Składanowski, T. Syczewski, J. Połowianiuk, S. Mazur (red.), Lublin 2015, s. 111). 


\section{„Grzech pokoleniowy” i „uzdrowienie międzypokoleniowe”}

Na przełomie XX i XXI wieku w niektórych grupach charyzmatycznych i środowiskach związanych z celebrowaniem Mszy Świętych połączonych z modlitwą o uzdrowienie lub nabożeństw o uzdrowienie pojawiła się myśl o „grzechach pokoleniowych” i o „uzdrowieniu międzypokoleniowym” (,uzdrowieniu drzewa rodowego"). W Internecie pojawiło się wiele informacji i artykułów na temat „uzdrowienia międzypokoleniowego" i jego praktykowania. Punktem wyjścia tych koncepcji jest zwykle książka o. Roberta De Grandis SSJ ${ }^{4}$. Opinie duchownych i świeckich zainteresowanych tym problemem są bardzo zróżnicowane i często sprzeczne, a nabożeństwa tego typu gromadzą tłumy. Budzi to zrozumiałe obawy, a dodatkowo, ze względu na niejasność teologiczną pojęć „grzech pokoleniowy” i „uzdrowienie międzypokoleniowe”, pojawiła się pilna potrzeba jednoznacznego wyjaśnienia i zaopiniowania tych zjawisk z punktu widzenia nauczania Kościoła 5 .

U podstaw tezy o grzechu pokoleniowym leży przekonanie, że grzechy przodków wywierają wpływ na życie obecnie żyjących członków rodziny, który może mieć wymiar duchowy i cielesny, wyrażać się w postaci jakiejś choroby, może też być powodem kłopotów w dziedzinie psychiki i niepowodzeń w życiu małżeńskim czy rodzinnym. Obciążenie grzechem dziedziczonym domaga się więc uwolnienia człowieka w modlitwie o uzdrowienie, którą należy objąć przodków sięgając w przeszłość nawet do piętnastego czy szesnastego pokolenia. Taka modlitwa obejmuje odmawianie egzorcyzmów, modlitwę wstawienniczą i Mszę Świętą. Idea „uzdrowienia międzypokoleniowego” wywodzi się od doktora

$4 \quad$ R. De Grandis, L. Schubert, Uzdrowienie międzypokoleniowe. Osobista podróż ku przebaczeniu, tł. B. Włodarczyk, Łódź 2003. Zjawisko to pojawiło się we współczesności na marginesie ludzkich chorób i cierpień oraz potrzeby pomocy duszpasterskiej, wynikającej z mocą imperatywu ze słów Jezusa Chrystusa „Nie potrzebują lekarza zdrowi, lecz ci, którzy się źle mają" (Mk 2, 17). Por. S. Płusa, Przebaczenie międzypokoleniowe. Spojrzenie teologiczno-praktyczne, „Duchowość w Polsce” 16 (2014), s. 101. Autor wskazuje (ibidem, s. 101-104), że inicjatorem takiego podejścia jest doktor Kenneth McAll, chirurg, misjonarz i psychiatra. Jako źródło informacji autor wskazuje na opracowanie M. Piotrowskiego, Uzdrowienie międzypokoleniowe. Terapia wedtug dr. Kennetha McAlla, „Miłujcie się” (2004) 1, s. 9-11. K. McAll opisał swoje doświadczenia w książce Healing the family tree, London 1982. Zob. Z o. Piotrem Różańskim SchP, duszpasterzem grupy Odnowy w Duchu Świętym Kanaw Łowiczu rozmawia Dorota Mazur, http://www.miesiecznikegzorcysta.pl/archiwum/ item/696-nie-dziedziczymy-grzechu-przodkow [21.03.2017]; Ł. Woźnicki, Nowa moda w kościele: uzdrawianie międzypokoleniowe, http://wyborcza.pl/1,76842,14943095,Nowa_moda_w_kosciele_uzdrawianie_miedzypokoleniowe.html [21.07.2015].

5 Por. Komisja Nauki Wiary Konferencji Episkopatu Polski, Opinia teologiczna Grzech pokoleniowy iuzdrowienie międzypokoleniowe. Problemy teologiczne ipastoralne (05.10.2015), nr 1, http://episkopat.pl/grzech-pokoleniowy-i-uzdrowienie-miedzypokoleniowe-problem y-teologiczne-i-pastoralne/ [17.03.2017]. 
Kennetha McAll'a (1910-2001), lekarza terapeuty i misjonarza anglikańskiego, który pod wpływem myśli chińskiej doszedł do wniosku, sam cierpiąc z powodu zaburzeń psychicznych, że duchy przodków odgrywają znaczącą rolę w chorobach somatycznych potomków. Jego prace dały początek poszukiwaniu uzdrowienia w minionych pokoleniach i na niego też powołuje się o. Robert De Grandis. Praktyka „uzdrowienia międzypokoleniowego” wywodzi się z tradycji zakorzenionej w wierzeniach religii wschodnich, otaczających kultem przodków i wierzących w reinkarnację. Jest więc skutkiem synkretyzmu religijnego, który wykształcił nowe zjawisko nazwane „reinkarnacją grzechu”. Opinia teologiczna Komisji Nauki Wiary Konferencji Episkopatu Polski dopatruje się przyczyn popularności tego zjawiska w zaniku poczucia grzechu, wraz z którym słabnie także zrozumienie autentycznej wolności, związanej z odpowiedzialnością za własne czyny. Dlatego odpowiedzialnością za swoje nieszczęścia i niepowodzenia próbuje się obciążyć przodków ${ }^{7}$, nie dostrzegając konieczności własnej przemiany. W takiej perspektywie uzdrowienie międzypokoleniowe stanowi formę usprawiedliwienia słabości oraz szukania łatwego wytłumaczenia i przebaczenia popełnionego zła ${ }^{8}$.

Zwolennicy koncepcji ,grzechu pokoleniowego" wskazują na fragmenty Pisma Świętego, mówiące niby o karze za grzechy przodków: „Pan, Twój Bóg, który karze występek ojców na synach do trzeciego i czwartego pokolenia" (Wj 20, 5); „Pan [...] zsyła kary za niegodziwość ojców na synów i wnuków aż do trzeciego i czwartego pokolenia” (Wj 34, 7); „Pan karze grzechy ojców na synach do trzeciego, a nawet czwartego pokolenia” (Lb 14, 18); „Jestem Bóg karzący nieprawość ojców na synach w trzecim i czwartym pokoleniu" (Pwt 5, 9). Jednak znajdujemy tam także wypowiedzi przeczące tezom o odpowiedzialności pokoleniowej9. Współczesna egzegeza wyjaśnia, że nie chodzi tu o dosłowną „nieprawość” czy „występek” ojców w znaczeniu ich grzechu osobistego, którego się dopuścili i za który odpowiedzialność poniosą ich dzieci, lecz o ich zły przykład dla dzieci, które, postępując podobnie jak ich ojcowie, umrą „za swój własny grzech"10. Poza tym cytowane fragmenty Biblii są trochę dłuższe i mają inne rozwinięcie - np. fragment „Pan, Bóg twój, który karze występek ojców na synach do trzeciego i czwartego pokolenia” ma swoje dopowiedzenie:

6 Por. ibidem, nr 2.

7 Tekst odwołuje się do E. C. Merino, R. Garcia de Haro, Teologia moralna fundamentalna, tt. A. Liduchowska, Kraków 2004, s. 459n.

8 Por. Komisja Nauki Wiary Konferencji Episkopatu Polski, Opinia teologiczna Grzech pokoleniowy i uzdrowienie międzypokoleniowe..., $\mathrm{nr} 3$.

$9 \quad$ Np. Jr 31, 29n; Ez 18, 3n.20; Pwt 24, 16.

10 Por. Komisja Nauki Wiary Konferencji Episkopatu Polski, Opinia teologiczna Grzech pokoleniowy i uzdrowienie międzypokoleniowe..., $\mathrm{nr} 4$. 
„okazuję zaś łaskę aż do tysiącznego pokolenia względem tych, którzy Mnie miłują i przestrzegają moich przykazań" (Wj 20, 5). Inny fragment tej samej księgi, ukazujący Boga jako zsyłającego kary aż do trzeciego i czwartego pokolenia, mówi równocześnie o Bogu, że jest „miłosierny i litościwy, bogaty w łaskę i wierność, zachowujący swą łaskę w tysiączne pokolenia” (Wj 34, 7). Dlatego cytowana opinia teologiczna mówi o manipulowaniu tekstami ${ }^{11}$. „Grzech pokoleniowy" stoi ponadto w sprzeczności z prawdą o Bożym miłosierdziu i Jego przebaczającej miłości. Ukazany przez Jezusa obraz Boga jako miłosiernego Ojca otwiera człowieka na możliwość zyskania Bożego przebaczenia, ułaskawienia w każdej sytuacji ${ }^{12}$.

Kościół zawsze nauczał, że grzech jest zawsze czymś osobistym i każdy osobiście ponosi karę za swój grzech: „każdy z nas o sobie samym zda sprawę Bogu” $(\mathrm{Rz} 14,12)^{13}$. W adhortacji Reconciliatio et paenitentia Jan Paweł II napisał,

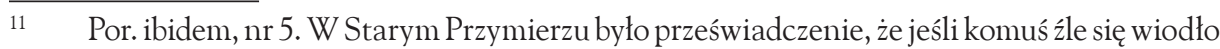
czy chorował, było to spowodowane jego złym życiem lub kogoś z jego rodziny. Wyrazem takiego przekonania były słowa uczniów skierowane do Jezusa: „Rabbi, kto zgrzeszył, że się urodził niewidomym - on czy jego rodzice?” Odpowiedź Jezusa jest bardzo jasna: „Ani on nie zgrzeszyl, ani rodzice jego, ale [stało się tak], aby się na nim objawiły sprawy Boże” (J 9, 1-3).

12 Por. ibidem, nr 6. Zob. M. Jagodziński, 156-159. „Powstaje wrażenie, że wnioskowanie o nich z powoływaniem się na tekst Pisma Świętego jest efektem poszukiwania biblijnych podstaw dla terapii stosowanej w psychiatrii. Może być ono także efektem specyficznie «duchowej» lektury Biblii - charakterystycznej dla hermeneutyki «protestanckiej» (z rodowodu i natury) - stawiającej na pierwszym miejscu jej subiektywne, własne rozumienie w przeświadczeniu, że jest ono darem Boga przemawiającego bezpośrednio do konkretnego człowieka. Znaczące jest w tym kontekście, że autorzy książek na te tematy z reguły nie przywołują na poparcie swojego rozumienia komentarzy biblijnych napisanych przez profesjonalnych biblistów, tak jakby specjalistyczna wiedza naukowa nie miała w tej kwestii nic do powiedzenia. Na fali subiektywizacji i indywidualizacji pojmowania religii takie postępowanie może nawet sprawiać wrażenie większej autentyczności, głębi i wnikliwości" (ibidem, nr 160).

13 Niepokojące jest w tym kontekście trwające przez tysiąclecia milczenie teologii i nauczania Kościoła na temat jakiegokolwiek „przebaczenia międzypokoleniowego”. Można by ewentualnie twierdzić, że doszło do odkrycia nowych aspektów życia duchowego, ale czyżby przez dwa tysiące lat Kościół nie zauważył problemu „uzdrowienia międzypokoleniowego”? (por. ibidem, s. 162). Jeśli zaś chodzi o teologię patrystyczną: „Komentarze Ojców charakteryzują się wprawdzie pewną rozbieżnością, ale nie potwierdzają teologii międzypokoleniowego dziedziczenia demonicznych obciążeń lub zniewoleń [...] dość powszechną nauką Ojców jest to, że tekst z Księgi Wyjścia (20, 5 i paralelne) odnosi się do sytuacji przed chrztem. Natomiast do ochrzczonego chrześcijanina stosują się inne miejsca Biblii, a zwłaszcza [...] (Ez 18, 2-3). Według św. Augustyna nie jest możliwe, aby duchowe skutki grzechu przetrwały chrzest, gdyż zostały utopione w wodzie chrztu. Przed chrztem człowiek żyje «pod Prawem», po chrzcie - w łasce. Augustyn uczył, że duchowe kary za grzechy przodków ponosi się tylko wtedy, kiedy powtarza się ich grzechy. Święty Jan Chryzostom z całą mocą występował przeciw idei ponoszenia duchowych konsekwencji 
że „grzech w znaczeniu prawdziwym i właściwym jest zawsze aktem konkretnej osoby, ponieważ jest aktem wolności poszczególnego człowieka, a nie aktem grupy czy wspólnoty" (nr 16). Człowiek nie ponosi kary za niepopełniony czyn, np. za grzech prapradziadka - zadośćuczynić i pokutować trzeba za swoje grzechy (zob. KKK nr 1459). Czymś innym są struktury grzechu, czyli sytuacje, które prowadzą do grzechu ${ }^{14}$. Jedynym grzechem przekazywanym z pokolenia na pokolenie jest grzech pierworodny, jednakże on „w żadnym potomku nie ma charakteru winy osobistej” (KKK nr 405), ,jest nazywany «grzechem» w sposób analogiczny" (KKK 404) ${ }^{15}$.

Cytowana opinia Komisji podkreśla, że teoria o „grzechu pokoleniowym” $\mathrm{i}$ „uzdrowieniu międzypokoleniowym” opiera się w dużej mierze na psychologii Carla Gustawa Junga i badaniach dr Kennetha McAll'a. Na ten temat wypowiedziała się Papieska Rada ds. Dialogu Międzyreligijnego w dokumencie Jezus Chrystus dawca wody życia - Chrześcijanska refleksja na temat New Age $(2003)^{16}$. Zostały w nim potępione błędne tezy Junga przejęte przez o. De Grandis, np. transcendentalny charakter świadomości i wprowadzenie idei nieświadomości zbiorowej jako swoistego magazynu symboli i wspomnień wspólnych dla ludzi w różnym wieku i z różnych kultur. Zdaniem tej Rady, Jung przyczynił się do „sakralizacji psychologii”, wprowadzając do niej elementy ezoterycznych spekulacji, twierdząc, że „psychologia jest współczesnym mitem i tylko w terminach bieżącego mitu możemy zrozumieć wiarę" (nr 2.3.2). Omawiane idee

są bardzo niebezpieczne dla życia duchowego wiernych i samej doktryny Kościoła. Propagowanie ich prowadzi do pewnego rodzaju „uspokajania” czy „wyciszania” sumień przez przerzucanie odpowiedzialności za swoje błędy, grzechy, popełnione

grzechu przez potomków. [...] nawet te kary, które określone są w Biblii jako trwające do trzeciego i czwartego pokolenia, to według Chryzostoma - podobnie jak i Augustyna - tylko konsekwencje społeczne. Na przykład po wyjściu z Egiptu wszyscy ponieśli konsekwencje grzechów niektórych (i wymarli na pustyni). [...] św. Tomasz z Akwinu, wielokrotnie omawiał problem kar do trzeciego $i$ czwartego pokolenia w «Sumie teologicznej». Jego wnioski można podsumować sentencją: dzieci nigdy nie ponosza duchowych konsekwencji grzechów swoich przodków (STh I-II, q. 81, a. 2). Mogą natomiast ponosić skutki społeczne (całe społeczeństwo cierpi za błędy minionych pokoleń) i skutki wychowania w negatywnie oddziałującej rodzinie (dziedziczenie patologii środowiskowej)" (A. Siemieniewski, http:// www.fronda.pl/a/uzdrowienie-miedzypokoleniowe,37679.html?part=2 [21.06.2015]).

14 Por. Komisja Nauki Wiary Konferencji Episkopatu Polski, Opinia teologiczna Grzech pokoleniowy i uzdrowienie międzypokoleniowe..., $\mathrm{nr} 7$.

15 Por. ibidem, nr 8. Zob. M. Jagodziński, s. 163-167.

16 www.google.pl/webhp?sourceid $=$ chrome-instant\&ion $=1 \&$ espv $=2 \& i e=U T F-8 \# q=P a p$ ieska+Rada+ds.+Dialogu+Mi\%C4\%99dzyreligijnego+w+dokumencie+Jezus+Chryst us+dawc $\%$ C4\% $85+$ wody $+\%$ C5\%BCycia+\%E2\%80\%93+Chrze $\% C 5 \% 9 B c i j a \% 5 \% 84 s$ ka+refleksja + na+temat + New + Age $+(2003) \& *$ [18.03.2017]. 
zło na poprzednie pokolenia. Zwalnia to wierzącego z postawy czujności, co staje się źródłem dalszych jego grzechów. Tymczasem chrześcijanina powinna cechować postawa nieustannego czuwania.... ${ }^{17}$.

\section{„Spowiedź furtkowa”}

Geneza „spowiedzi furtkowej” nie jest do końca znana, nikt nie podaje jej sprecyzowanej definicji, a praktyka się upowszechnia. Nazwa jest niejasna i tajemnicza, niekiedy mówi się o spowiedzi generalnej połączonej z modlitwą o uwolnienie. Istota tej spowiedzi polega na zamykaniu „furtek” (stąd nazwa „furtkowa”), które grzech (osobisty lub „pokoleniowy”) otwarł przed szatanem, dając mu w ten sposób pewną władzę nad człowiekiem. Cechą charakterystyczną tej spowiedzi jest bardzo rozbudowany, ale ograniczony do pierwszego przykazania Dekalogu (stąd nie jest to spowiedź generalna), rachunek sumienia oraz modlitwa o uwolnienie, czasem przybierająca formę uroczystego egzorcyzmu. Tego rodzaju praktyka domaga się pogłębionej refleksji oraz oceny teologicznej i pastoralnej ${ }^{18}$.

Komisji Nauki Wiary KEP zaznacza, że możemy mieć tu do czynienia z synkretyzmem polegającym na łączeniu sakramentu pokuty z elementami psychoterapii i egzorcyzmu. Są to jednak różne płaszczyzny niesienia pomocy człowiekowi, a przekraczanie granic ich kompetencji może prowadzić do poważnej szkody psychicznej i duchowej penitenta. Ponadto przyzwolenie na wprowadzenie nowej formy sakramentu pokuty bez zgody władz kościelnych może uruchomić lawinę pomysłów na „ulepszanie” tego sakramentu, co grozi

$17 \quad$ Komisja Nauki Wiary Konferencji Episkopatu Polski, Opinia teologiczna Grzech pokoleniowy i uzdrowienie międzypokoleniowe..., nr 9. Specyficznym zagrożeniem poprawności argumentacji środowisk charyzmatycznych jest także opieranie się prawie wyłącznie na publikacjach mających charakter „literatury wsobnej” - tworzonej tylko w tych środowiskach (por. M. Jagodziński, s. 161).

18 Opinia teologiczna Komisji Nauki Wiary KEP w sprawie tzw. spowiedzi furtkowej, http:// episkopat.pl/decyzja-kep-w-sprawie-tzw-spowiedzi-furtkowej/, nr 1 [19.03.2017]. Więcej informacji o początkach tej koncepcji i praktyki podaje Opinia komisji teologicznej w sprawie tzw. spowiedzi furtkowej autorstwa Wydziału Teologii KUL, http://www.diecezja. rzeszow.pl/2015/03/opinia-komisji-teologicznej-w-sprawie-tzw-spowiedzi-furtkowej/, nr 1 [19.03.2017]: „Zwykle wskazuje się na założony w 2006 r. Krąg Miłosierdzia Kapłanów, skupiający księży żyjących charyzmatem Wspólnoty Sióstr Służebnic Bożego Miłosierdzia w Rybnie koło Sochaczewa". W dalszych numerach obydwie cytowane opinie są jednobrzmiące. Zob. „Spowiedź furtkowa” - magiczne praktyki we wsi pod Sochaczewem. Księża „psychologowie” przepytująo grzechy przodków, http://natemat.pl/137153,magiczne-praktykiwe-wsi-pod-sochaczewem-ksieza-lacza-spowiedz-z-amatorska-psychologia-przepytuja-ogrzechy-przodkow [20.03.2017]. 
chaosem, a ostatecznie rozbiciem jedności sakramentu, pogonią za nadzwyczajnością i niezwykłymi szafarzami ${ }^{19}$.

Istotną kwestią jest badanie przez obszerny zestaw pytań (o penitenta, rodzinę, przodków), czy popełnione w przeszłości grzechy nie są otwartymi „furtkami” dla złego ducha, co sugeruje przy okazji, że potomstwo ponosi konsekwencje grzechów przodków ${ }^{20}$. Poważnym nadużyciem jest też wprowadzanie w ryt sakramentu pokuty modlitwy o uwolnienie, czasem w formie uroczystego egzorcyzmu (podważa ona skuteczność wcześniej udzielonego sakramentalnego rozgrzeszenia, chociaż sama spowiedź jest już egzorcyzmem, a uwolnienie od winy jest owocem absolutnego usprawiedliwienia w rozgrzeszeniu) ${ }^{21}$. Groźne jest również szukanie nowych spowiedników, by zlokalizować „furtkę” i zamknąć ją ostatecznie; wiąże się z tym wielokrotne powtarzanie tej samej spowiedzi aż do skutku. To może prowadzić do skrupułów oraz osłabienia wiary w nieograniczoną moc Bożego Miłosierdzia i zakłada, że jakiś grzech niewyznany bez winy penitenta pozostaje nieodpuszczony i może stanowić „furtkę” dla złego ducha (według nauki Kościoła do ważności spowiedzi wymagana jest zupełność formalna wyznania grzechów, a nie materialna) ${ }^{22}$. Nieuzasadnione jest także przekonanie, że tylko określone wykroczenia otwierają „furtkę” dla złego ducha. W konsekwencji rachunek sumienia ogranicza się bezzasadnie do jednego (zwykle pierwszego) przykazania ${ }^{23}$, co poważnie narusza integralność tego sakramentu, a do tego dochodzi spowiadanie się z cudzych grzechów (tzw. pokoleniowych). Kościół nie zna takiej praktyki ${ }^{24}$. Zastrzeżenia budzi również sposób przeprowadzania rachunku sumienia, przy którym podstawą musi być wolność penitenta i świadomość jego sumienia. Spowiednik powinien wesprzeć penitenta, ale monstrualnie rozbudowany rachunek sumienia pod kątem grzechów otwierających rzekomo „furtki” dla szatana jest koncentrowaniem się na nim jako głównym sprawcy zła, a nie na pełnej prawdzie o człowieku ${ }^{25}$.

19 Por. Opinia teologiczna Komisji Nauki Wiary KEP w sprawie tzw. spowiedzi furtkowej, nr 2 i 4. Inną ocenę przedstawia np. opublikowany w Internecie tekst Demony a „Spowiedź furtkowa", rozmawiała Maria Patynowska, Fronda.pl, http://www.jp2w.pl/pl/37921/122599/ Demony_a_Spowiedz_furtkowa.html [21.03.2017].

20 Por. Opinia teologiczna Komisji Nauki Wiary KEP w sprawie tzw. spowiedzi furtkowej, nr 3.

21 Por. ibidem, nr 4.

22 Por. ibidem, nr 5.

23 KKK nr 1456 za Soborem Trydenckim stwierdza wyraźnie, że podczas spowiedzi winno się wyznać wszystkie grzechy śmiertelne, „chociaż byłyby najbardziej skryte i popełnione przeciw dwu ostatnim przykazaniom Dekalogu, ponieważ niekiedy ciężej one ranią duszę i są bardziej niebezpieczne niż te popełnione jawnie".

24 Por. Opinia teologiczna Komisji Nauki Wiary KEP w sprawie tzw. spowiedzi furtkowej, nr 6.

25 Por. ibidem, nr 7. 
Miejscem uwrażliwiania wiernych na zagrożenia duchowe jest szeroko rozumiane nauczanie kościelne, zwłaszcza wspólnotowe słuchanie słowa Bożego w obrzędzie pojednania wielu penitentów $z$ indywidualną spowiedzią czy też nabożeństwo pokutne ${ }^{26}$. Rozwiązanie spraw trudnych i patologicznych nie jest możliwe w konfesjonale, wymagają one dłuższej rozmowy lub kierownictwa duchowego. W samej spowiedzi, zamiast tracić czas na szukanie szatańskich „furtek”, należy otwierać wiernych na słowo Boże, zaufanie w moc Bożej łaski, przemianę w myśleniu i życie Ewangelią ${ }^{27}$.

Omawiana opinia teologiczna formuluje pod adresem „spowiedzi furtkowej” szereg zastrzeżeń o charakterze dogmatycznym. Ponieważ głównym motywem jej poszukiwania jest prawdopodobnie doświadczenie zniewolenia jakimś złem, które odbiera panowanie nad życiem, trzyma człowieka na uwięzi i ściąga w dół - jawi się ona jako oferta wyzwolenia. Źródła zniewolenia człowieka mogą być jednak bardzo różne i niekoniecznie mają charakter demoniczny. Pierwszym i podstawowym źródłem zniewolenia jest grzech, który nie jest tylko aktem nieposłuszeństwa względem Boga, ale także mocą, która zniewala człowieka i nim włada (por. J 8, 34; Ga 4, 3). Tej zniewalającej mocy grzechu nie należy identyfikować z mocą złego ducha, gdyż Biblia ukazuje wprawdzie związek między nim a grzechem, ale człowiek mógłby zgrzeszyć także bez pomocy szatana. Właściwe źródło grzechu nie leży więc poza człowiekiem, ale w nim samym - jest nim wolność - jedyna „furtka” dla zła.

Błędem jest zatem nazywanie grzechu „furtką”, przez którą szatan niepostrzeżenie wkrada się w życie człowieka i staje się jego cichym reżyserem. Wizja taka może stać się niebezpieczną strategią spychania winy na innych, a nawet postrzegania siebie w kategoriach ofiary: [...] W konsekwencji demonizowanie rzeczywistości może prowadzić do wymawiania się od odpowiedzialności za zło, u którego początku stoją nasze osobiste decyzje i czyny. W Sakramencie Pokuty i Pojednania człowiek otrzymuje szansę stanięcia w prawdzie i doświadczenia wyzwalającej mocy Bożego miłosierdzia. Wciąz jednak pozostaje w nim „zarzewie grzechu” (fomes peccati), które Sobór Trydencki nazywa także „pożądliwością” (concupiscentia). Określenia te wskazują na pewną skłonność ludzkiej woli do zła. Jest ona skutkiem grzechu pierworodnego i pozostaje także w człowieku usprawiedliwionym przez Chrystusa a więc po chrzcie św. Do tego dochodzą różne skłonności naturalne, których źródła tkwią w konkretnych uwarunkowaniach biologicznych, społecznych i kulturowych. Swoją rolę mogą odgrywać także różnego rodzaju zranienia w sferze psychicznej i duchowej, sięgające nieraz głębokich pokładów ludzkiej osobowości. W takiej

$26 \quad$ Por. ibidem, nr 8.

27 „W takiej perspektywie «spowiedź furtkowa» jawi się nawet jako szatańska prowokacja. Sakrament pokuty zamiast stać się miejscem spotkania człowieka z miłosierną miłością Boga, która uzdrawia i leczy, staje się napawającą lękiem konfrontacją z siłami zła" (ibidem, nr 9). 
perspektywie staje się jasne, że sakramentu pokuty nie można traktować w sposób magiczny. Uzdrowienie/wyzwolenie, które rzeczywiście się w nim dokonuje, jest procesem, gdyż ma ono zawsze na uwadze ludzką wolność i respektuje całą złożoną strukturę ludzkiej osoby. Niestety, przy okazji „spowiedzi furtkowej” element ten niemal wcale nie dochodzi do głosu. W konsekwencji zachodzi niebezpieczeństwo składania penitentowi nierealnych obietnic, których niespełnienie spotęguje w nim tylko poczucie rozczarowania i frustracji. W życiu duchowym nie ma automatyzmu. Nie można w jednym momencie przekreślić dwudziestu lat życia w nałogu lub zmagania się z jakimś bolesnym problemem i zacząć wszystko od nowa. Nie taka jest biblijna wizja człowieka i Zbawienia. Łaska Boża nie jest jakimś „dobrym fatum”, które niejako za plecami człowieka wszystko prowadzi ku dobremu. [...] Bóg nie łamie natury, ale respektuje prawa, które sam jej nadał ${ }^{28}$.

Opinia teologiczna KEP zaznacza, że w ostatnim czasie spotykamy się z przesadnym podkreślaniem roli szatana w życiu jednostek i społeczności. Mówi się nawet o „złu pokoleniowym”, którego destruktywna moc może przetrwać po przyjęciu chrztu św. Nietrudno dostrzec w tym tendencje dualistyczne, które nie znajdują żadnego uzasadnienia w chrześcijańskiej wizji Boga, świata i człowieka. Kościół zawsze głosił, że całe stworzenie jest dobre, gdyż ma swoje źródło w Bogu, który jest dobrem absolutnym.

Nie ma zatem jakiejś złej energii (duchowej lub materialnej), która przenikałaby rzeczywistość, i którą można by wykorzystać w dobrym bądź złym celu (np. przy pomocy magicznych zaklęć, radiestezji itd.). Także szatan jest ontologicznie dobry, a zło, które czyni, wynika z wolności jego decyzji. Zło jest brakiem należnego dobra (privatio boni), w związku z czym nie może być ani bytem substancjalnym, ani żadnym pozytywnym stanem rzeczy (wszystko co jest, jest dobre: ens et bonum convertuntur). W przeciwnym razie należałoby przyjąć istnienie dwóch pryncypiów, będących źródłem dobra i zła, co jednak pozostaje w głębokiej sprzeczności z chrześcijańską nauką o stworzeniu. Jeśli mówi się czasem o „złu metafizycznym” (Leibniz), to akcentuje się jedynie egzystencjalną i istotową ograniczoność bytu na tle bytu absolutnego. Teologia chrześcijańska nie wyklucza wprawdzie działań szatańskich i demonicznych, uznając je za jedno ze źródeł grzechu, jednak ich nie wyolbrzymia. Chrześcijanin żyje świadomością, że Chrystus pokonał moce szatańskie, i że to Jego zwycięstwo ma charakter ostateczny i nieodwołalny (por. J 12, 31; Ef 1, 20-22; Kol 2, 15; Ap 12, 9). Szatan w żadnym wypadku nie jest równym przeciwnikiem Boga. Nie przysługuje mu też żadna władza nad człowiekiem. Dzięki zwycięstwu Chrystusa na krzyżu człowiek odzyskał utraconą wolność i może stać się uczestnikiem królestwa Bożego. To wyzwolenie człowieka jest wyzwoleniem „od”, a jednocześnie wyzwoleniem „ku”; wyzwoleniem, umożliwiającym podejmowanie czynów prowadzących do zbawczego zjednoczenia z Bogiem i ukazujących w świecie Chrystusowe zwycięstwo na krzyżu ${ }^{29}$.

28 Ibidem, nr 10.

29 Ibidem, nr 11. Por. A. Siemieniewski, Problem spowiedzi furtkowej, rozmawiała Monika Odrobińska, http://www.idziemy.com.pl/kosciol/problem-spowiedzi-furtkowej/ [20.03.2017]. 
Charakterystyczne dla zwolenników „spowiedzi furtkowej” demonizowanie rzeczywistósci wiąze się także ze zdecydowanie negatywną oceną religii niechrześcijańskich, zwłaszcza religii Wschodu, a II Sobór Watykański stwierdza wyraźnie: „Kościół katolicki nic nie odrzuca z tego, co w religiach owych prawdziwe jest i święte. Ze szczerym szacunkiem odnosi się do owych sposobów działania i życia, do owych nakazów i doktryn, które chociaż w wielu wypadkach różnią się od zasad przez niego wyznawanych i głoszonych, nierzadko odbijają promień owej Prawdy, która oświeca wszystkich ludzi” (DRN nr 2) ${ }^{30}$.

\section{Zalecenia i regulacje prawne}

W odniesieniu do koncepcji ,grzechu pokoleniowego” i „przebaczenia międzypokoleniowego" Komisja Nauki Wiary Konferencji Episkopatu Polski stwierdziła, że tego typu praktyki zdradzają bardzo wyraźnie „brak wiary, czy przynajmniej niedowierzanie w skuteczność łaski sakramentalnej, na pierwszym miejscu chrztu św. W tym sakramencie zostajemy wyzwoleni z wszelkiego grzechu. Owszem pozostają w ochrzczonym pewne doczesne konsekwencje grzechu, takie jak cierpienie, choroba, śmierć, czy nieodłączne od życia ułomności, takie jak słabości charakteru, a także skłonność do grzechu. Jednak wszelki grzech jest zmazany"31. Dlatego postulowała, by władza kościelna jednoznacznie ostrzegała przed używaniem w przepowiadania pojęć "grzech pokoleniowy” i „uzdrowienie międzypokoleniowe” oraz zakazała celebrowania Mszy Świętych i nabożeństw z modlitwą o uzdrowienie z „grzechów pokoleniowych" czy o „uzdrowienie międzypokoleniowe”. Przypomniała także, że najróżniejsze formy praktykowanej przez wieki modlitwy o uzdrowienie chorych, także w ramach liturgii Mszy Świętej, powinny być celebrowane zgodnie z przepisami ksiąg liturgicznych oraz instrukcją Kongregacji Nauki Wiary Ardens felicitatis desiderium (2003) 32. W przepowiadaniu należy zadbać o jasny wykład nauki Kościoła na temat grzechu pierworodnego i jego skutków, rozumienia grzechów osobistych i ich skutków społecznych, skuteczności łaski sakramentalnej, zwłaszcza chrztu ${ }^{33}$ oraz sakramentu pokuty i pojednania, kwestii pojednania

30 Por. Opinia teologiczna Komisji Nauki Wiary KEP w sprawie tzw. spowiedzi furtkowej, nr 12.

31 Komisja Nauki Wiary Konferencji Episkopatu Polski, Opinia teologiczna Grzech pokoleniowy i uzdrowienie międzypokoleniowe..., $\mathrm{nr} 10$.

32 Kongregacja Nauki Wiary, Ardens felicitatis desiderium, Wrocław 2003.

33 Por. M. Jagodziński, Das Sakrament der Taufe als Communio-Sakrament, „Roczniki Teologiczne" 63 (2016) z. 7, s. 213. 
z Bogiem i z ludźmi, poczucia winy i przebaczenia oraz przypominać, jak ważna jest żywa wiara w przyjmowaniu sakramentów ${ }^{34}$.

Druga z omówionych opinii Komisja Nauki Wiary KEP postulowała wprowadzenie oficjalnego zakazu praktyki tzw. spowiedzi furtkowej i stwierdziła, że jej rolę dobrze spełnia wypróbowana i przyjęta w Kościele praktyka spowiedzi generalnej. Duszpasterzom zaleciła częstsze sprawowanie sakramentu pokuty i pojednania $w$ formie nabożeństwa pokutnego $z$ indywidualnym wyznaniem grzechów i rozgrzeszeniem, zachęcanie wiernych do korzystania z kierownictwa duchowego oraz różnych rekolekcji, a w przypadku uzasadnionej konieczności do korzystania z pomocy psychoterapeuty lub diecezjalnego egzorcysty ${ }^{35}$.

Zbawienie darowane ludziom już w Starym Testamencie miało kształt społeczny, a grzech oznaczał zakłócenie Bosko-ludzkich odniesień wspólnotowych, fundamentalny defekt komunikacji i komunii. Odpowiednio do tego pokuta i pojednanie były też sprawą całej wspólnoty. W Nowym Testamencie Jezus sam przebaczał grzechy i wzywał do przemiany, a swoją władzę przekazał chrześcijańskiej wspólnocie. Tak więc sam Kościół jest w Jezusie Chrystusie sakramentalnym znakiem odpuszczenia i pojednania ${ }^{36}$, a wyznanie grzechów miało za cel umożliwienie modlitwy wstawienniczej całej wspólnoty kościelnej. II Sobór Watykański przywrócił sakramentowi pokuty zapomniane wymiary personalne i eklezjalne. Nowsza teologia postrzega je jako splecione ze sobą. Ma to szczególne znaczenie w obliczu wzmagającego się współcześnie pragnienia wspólnoty i ponownego odkrycia komunijnego charakteru Kościoła. Darowane przez Boga pojednanie dosięga grzesznego człowieka pośród braterskiej pomocy w nawróceniu, przezwycięża niepokój, izolację i wyobcowanie, zaprowadzając

34 Komisja Nauki Wiary Konferencji Episkopatu Polski, nr 10. Por. M. Jagodziński, s. 168n: „Niewątpliwie trzeba zgodzić się i podkreślić, że omawiane powiązania i społeczne wpływy grzechu wymagają walki duchowej i przede wszystkim ewangelizacji. Trzeba jednak bronić się przed implementacją do wiary chrześcijańskiej przekonań i praktyk wynikających jedynie z pobożności, chęci pomocy i prób logicznej dedukcji, niepotwierdzonych przez tradycję teologiczną Kościoła, pozornie użytecznych duchowo i ewangelizacyjnie, a przy okazji zagrażających integralności kościelnego nauczania na temat skuteczności sakramentów chrztu i pojednania. W sakramentach działa sam Jezus Chrystus, toteż nic nie może brakować skuteczności tego działania, a Jego Duch przenika wszystko do końca. Jakiekolwiek ograniczenia skuteczności tego działania mogą pochodzić tylko od ludzi, którym często niełatwo przychodzi otworzyć się w pełni na moc Boga i w doskonały sposób poddać życie Jego Zbawieniu. Dlatego właśnie istnieje paląca potrzeba nasilonej ewangelizacji. Tradycja teologiczna Kościoła zna modlitwę o uzdrowienie i uwolnienie, ale nie w wymiarze międzypokoleniowym, toteż trzeba całkowicie zarzucić kategorię «uzdrowienia międzypokoleniowego» i jak najszybciej o niej zapomnieć”.

35 Opinia teologiczna Komisji Nauki Wiary KEP w sprawie tzw. spowiedzi furtkowej, nr 13.

36 Por. A. Skowronek, Sakrament pojednania. Wina. Grzech. Pojednanie, Włocławek 1995, s. 134. 
jednocześnie pokój, komunikację i tożsamość37. Kościół musi ciągle stawiać sobie pytanie, czy zadbał o odpowiednią hermeneutykę doświadczenia i wyznania grzechu, czy oferowane przez niego kody i drogi komunikacji pomagają grzesznym ludziom doświadczyć przebaczenia win przez Boga oraz przezwyciężenia upadków? ${ }^{38}$ Dlatego nie powinno się wyrywać sakramentu pokuty z kontekstu wspólnotowego i tracić $z$ oczu aspektu solidarnościowego ${ }^{39}$. Komunikacyjno-komunijny charakter sakramentu pojednania i pokuty domaga się utrwalenia odnowionego rytu sprawowania go we wspólnocie ${ }^{40}$.

Nic więc dziwnego, że Konferencja Episkopatu Polski podczas 368. Zebrania Plenarnego w Warszawie w dniach 11-12 marca 2015 roku na podstawie art. 9 Statutu KEP podjęła decyzję o zakazie stosowania praktyki „spowiedzi furtkowej" ${ }^{41}$.

Słowa kluczowe: grzech, sakrament chrztu, sakrament pokuty, odpuszczenie grzechów, Zbawienie, ,grzech pokoleniowy”, „przebaczenie międzypokoleniowe”, „spowiedź furtkowa”

\section{Bibliografia:}

1. Beinert W., Versöhnung als Lebensvollzug der Kirche, [w:] Theorie der Sprachhandlung und heutige Ekklesiologie. Ein philosophisch-theologisches Gespräch, P. Hünermann, R. Schaeffler (red.), Freiburg - Basel - Wien 1980, s. 130-149.

2. De Grandis R., L. Schubert, Uzdrowienie międzypokoleniowe. Osobista podróż ku przebaczeniu, tł. B. Włodarczyk, Łódź 2003.

3. Demony a "Spowiedź furtkowa”, rozmawiała Maria Patynowska, Fronda.pl, http://www.jp2w.pl/pl/37921/122599/Demony_a_Spowiedz_furtkowa.html [21.03.2017].

37 Por. F.-J. Nocke, Sakramententheologie. Ein Handbuch, Düsseldorf 1997, s. 210n.

38 Por. H.O. Meuffels, Kommunikative Sakramententheologie, Freiburg - Basel - Wien 1995, s. 323; W. Beinert, Versöhnung als Lebensvollzug der Kirche, [w:] Theorie der Sprachhandlung und heutige Ekklesiologie. Ein philosophisch-theologisches Gespräch, P. Hünermann, R. Schaeffler (red.), Freiburg-Basel-Wien 1980, s. 145-147; L. Lies, Sakramententheologie. Eine personale Sicht, Graz - Wien - Köln 1990, s. 351-355.

39 Por. P. Guilluy, Vergebung und Schuld, [w:] Neue Summe Theologie, Bd. 2: Dieneue Schöpfung, P. Eicher (red.), Freiburg - Basel - Wien 1989, s. 197n; M. Jagodziński, Komunijna wizja sakramentu pokuty i pojednania, [w:] Czy można dzisiaj wzywać do nawrócenia $i$ pokuty? Chrześcijańska odpowiedź wiary, M. Składanowski, T. Syczewski, J. Połowianiuk (red.), Lublin 2015, s. 84-90.

40 Obrzędy pokuty dostosowane do zwyczajów diecezji polskich, Katowice 2002, nr 22.

41 Decyzja nr 2/368/2015 z dnia 12 marca 2015 r., http://episkopat.pl/decyzja-kep-w-sprawie-tzw-spowiedzi-furtkowej/ [20.03.2017]. 
4. Fiedoruk P., Bosko-ludzka relacja w sakramencie spowiedzi, [w:] Pokuta w życiu chrześcijańskim, M. Składanowski, T. Syczewski, J. Połowianiuk, S. Mazur (red.), Lublin 2015, s. 101-127.

5. Guilluy P., Vergebung und Schuld, [w:] Neue Summe Theologie, Bd. 2: Die neue Schöpfung, red. P. Eicher, Freiburg - Basel - Wien 1989, s. 171-204.

6. Jagodziński M., Czy istnieje kwestia „przebaczenia międzypokoleniowego”?, „Roczniki Teologiczne", 63 (2016) z. 2, s. 155-169.

7. Jagodziński M., Das Sakrament der Taufe als Communio-Sakrament, „Roczniki Teologiczne" 63 (2016) z. 7, s. 201-219.

8. Jagodziński M., Komunijna wizja sakramentu pokuty i pojednania, [w:] Czy można dzisiaj wzywać do nawrócenia i pokuty? Chrześcijańska odpowiedź wiary, M. Składanowski, T. Syczewski, J. Połowianiuk (red.), Lublin 2015, s. 73-93.

9. Jan Paweł II, Adhortacja Reconciliatio et paenitentia (1984).

10. Katechizm Kościoła Katolickiego (1994) (wyd. pol. Poznań 22002).

11. Komisja Nauki Wiary Konferencji Episkopatu Polski, Opinia teologiczna Grzech pokoleniowy $i$ uzdrowienie międzypokoleniowe. Problemy teologiczne $i$ pastoralne (05.10.2015), http://episkopat.pl/grzech-pokoleniowy-i-uzdrowienie-miedzypok oleniowe-problemy-teologiczne-i-pastoralne/ [17.03.2017]

12. Kongregacja Nauki Wiary, Instrukcja Ardens felicitatis desiderium (2003), Wrocław 2003.

13. Lies L., Sakramententheologie. Eine personale Sicht, Graz - Wien - Köln 1990.

14. McAll K., Healing the family tree, London 1982.

15. Merino E. C., Garcia de Haro R., Teologia moralna fundamentalna, tł. A. Liduchowska, Kraków 2004.

16. Meuffels H. O., Kommunikative Sakramententheologie, Freiburg - Basel - Wien 1995.

17. Nocke F.-J., Sakramententheologie. Ein Handbuch, Düsseldorf 1997.

18. Obrzędy pokuty dostosowane do zwyczajów diecezji polskich, Katowice 2002.

19. Opinia teologiczna Komisji Nauki Wiary KEP w sprawie tzw. spowiedzi furtkowej, http://episkopat.pl/decyzja-kep-w-sprawie-tzw-spowiedzi-furtkowej/ [19.03.2017].

20. Papieska Komisja Biblijna, Interpretacja Pisma Świętego w Kościele. Przemówienie Ojca Świętego Jana Pawła II oraz Dokument Papieskiej Komisji Biblijnej, tł. K. Romaniuk, Poznań 1994.

21. Papieska Rada ds. Dialogu Międzyreligijnego, Jezus Chrystus dawca wody życia - Chrześcijańska refleksja na temat New Age (2003), https:/www.google.pl/ webhp? sourceid $=$ chrome-instant\&ion $=1$ \&espv $=2$ \&ie $=U T F-8 \# q=$ Papieska + Rada +ds. + Dialogu + Mi\%C4\%99dzyreligijnego + w + dokumencie + Jezus +C hrystus + dawc $\%$ C4\%85+wody + \%C5\%BCycia + \%E2\%80\%93+Chrze\%C5\%9 Bcija\%C5\%84ska+ refleksja+ na+temat+New +Age+ (2003) \&* [20.03.2017].

22. Piotrowski M., Uzdrowienie międzypokoleniowe. Terapia wedlug dr. Kennetha McAlla, „Miłujcie się” 1 (2004), s. 9-11.

23. Płusa S., Przebaczenie międzypokoleniowe. Spojrzenie teologiczno-praktyczne, „Duchowość w Polsce" 16 (2014), s. 101-112.

24. Sesboüé B., Jezus Chrystus jedyny Pośrednik. Rzecz o odkupieniu i zbawieniu, t. II: Opowiadania o zbawieniu. Propozycja soteriologii narratywnej, tł. A. Kuryś, Poznań 2016. 
25. Siemieniewski A., http://www.fronda.pl/a/uzdrowienie-miedzypokoleniowe,37679. html?part=2 [21.06.2015].

26. Siemieniewski A., Problem spowiedzi furtkowej, rozmawiała Monika Odrobińska, http:// www.idziemy.com.pl/kosciol/problem-spowiedzi-furtkowej/ [20.03.2017].

27. „Spowiedź furtkowa”- magiczne praktyki we wsi pod Sochaczewem. Księża „psychologowie” przepytuja o grzechy przodków, http://natemat.pl/137153,magiczne-praktyki-we-wsipod-sochaczewem-ksieza-lacza-spowiedz-z-amatorska-psychologia-przepytuja-ogrzechy-przodkow [20.03.2017].

28. Skowronek A., Sakrament pojednania. Wina. Grzech. Pojednanie, Włocławek 1995.

29. Woźnicki Ł., Nowa moda w kościele: uzdrawianie międzypokoleniowe, http://wyborcza. pl/1,76842,14943095,Nowa_moda_w_kosciele_uzdrawianie_miedzypokoleniowe. html [21.07.2015].

30. Z o. Piotrem Różańskim SchP, duszpasterzem grupy Odnowy w Duchu Świętym Kana $w$ Łowiczu rozmawia Dorota Mazur, http://www.miesiecznikegzorcysta.pl/archiwum/ item/696-nie-dziedziczymy-grzechu-przodkow [21.07.2015]. 